\title{
Practicum-Based Inquiry Learning to Improve the Scientific Attitude of Students at SMA Negeri 1 Suka Makmur Aceh Besar
}

\author{
Indah Suryawati $^{1^{*}}$, Nurul Akmal ${ }^{2}$ \\ ${ }^{1}$ Department of Primary School Teacher Education, Faculty of Teacher Training and \\ Education, Universitas Serambi Mekkah, Aceh, Indonesia \\ ${ }^{2}$ Department of Biology Education, Faculty of Teacher Training and Education, \\ Universitas Serambi Mekkah, Aceh, Indonesia \\ *Corresponding Author: Indah Suryawati, indah.suryawati@serambimekkah.ac.id.
}

\begin{abstract}
The purpose of this study was to determine the increase in scientific attitudes of students taught by practicum-based inquiry learning. The research started with the preparation of the scientific attitude observation sheet instrument. The analyzed data are qualitative. Qualitative data of this study was data from the observation of students' scientific attitudes using the percentage formula. The method used in this study was a quasi-experimental method: treatment of one variable and no control classwith pretest-posttest design. This research used a descriptive research to describe students' scientific attitudes. The average value of the highest scientific attitude of students was on the open aspect of $70.27 \%$, while the average value of the lowest scientific attitude of students was on the curiosity indicator of $56.33 \%$. Thus, it can be concluded that the students' scientific attitude increased through the process of practical activities on arthropods and molluscs material using inquiry learning occurred with a fairly good category $63.82 \%$.
\end{abstract}

Keywords: inquiry learning, practicum-based, scientific attitude.

\section{Introduction}

Learning of Biology has a major contribution in building human resources with the character, the characteristics of their knowledge, and the nature of learning, that always emphasizes processes, products, and their applications to develop students' skills and behavior. Schools with various visions and missions must be realized. Among the things to be realized in biology subjects that are trying to educate students with superior knowledge and skills, have a work ethic, train to conduct research under scientific processes or methods, and learn by applying their best knowledge, have a disciplined, honest attitude and responsible.

Characteristics of science and the essence of learning Biology that always emphasizes the process, product, and implementation, making Biologyone of the subjects that have a great contribution in building Human Resources (HR) with good character. However, in reality, there are still many students who consider Biology as a boring subject that results in low student learning outcomes.The initial observations at SMA Negeri 1 Suka Makmur found that about $37.2 \%$ of students scored below the minimum level score in Biology. In addition, the results of initial interviews with teachers also obtained information that practicum activities are still rarely carried out in the school so that students' understanding is only limited to concepts, not deeply appreciated. This is what is likely to be one of the causes of low student learning outcomes, so we need an appropriate form of the learning process in teaching a concept to improve student learning outcomes. One of the lessons that are thought to be appropriate to be applied is practicum-based inquiry learning. Learning with an inquiry approach that requires students to find and solve their problems is thought to be able to increase students' problem-solving abilities so that 
student learning outcomes also increase. In addition, in the implementation of the practicum-based inquiry learning process, science process skills are also needed that can assist students in understanding the material based on practical steps such as classifying, observing, analyzing, communication, asking questions, and interpreting.

Elster (2011) stated that the inquiry is a scientific activity that has various activities that involve observing, asking questions, evaluating books and other sources of information looking at what has been understood, then planning an investigation, reviewing what is already known based on evidence. investigate, use tools to collect, analyze, and interpret data, propose answers, explain and predict, and think logically and consider alternative explanations through finding answers to questions. Besides, Sagala (2008) mentioned that the inquiry method is a learning method that seeks to instill the basics of scientific thinking in students.So that, in this learning process, students learn more to develop creativity in solving problems. Students are placed as the subject of learning. The teacher's role in learning with the inquiry method is as a guide and facilitator.

Based on the problems that have been raised, wewere interested in making a study with the title "Practice-Based Inquiry Learning to Improve Students' Scientific Attitude at SMA Negeri 1 Suka Makmur Aceh Besar".

2. Method

This research was conducted at SMA Negeri 1 Suka Makmur, Aceh Besar. The choice of this school as a research location was because SMA Negeri 1 Suka Makmurwas one of the schools that open to new innovations making it easier for researchers to conduct research. The sample selection in this study used a purposive sampling technique because of the molluscs and anthropoids material practicum.

The method used in this study was a quasi-experimental method, namely treatment of one variable and no control class (Sukmadinata, 2005), with "one group of pretestposttest design". This research used descriptive research to describe students' scientific attitudes.

\section{Results and Discussions}

The results of observing students' scientific attitudes in learning of vertebrate zoology are presented in Table 1.Table 1 shows that the category of students' scientific attitudes using inquiry learning in the concept of arthropods and mollusks was increased from the first meeting to the third meeting.

Table 1. Students' Scientific Attitudes on the Concept Molluses and Anthropoids

\begin{tabular}{clccc}
\hline No & $\begin{array}{c}\text { Scientific attitude } \\
\text { aspect }\end{array}$ & Meeting I & Meeting II & Meeting III \\
\hline 1 & Want to know & $51.00 \%$ & $58.00 \%$ & $60.00 \%$ \\
2 & Critical & $46.00 \%$ & $63.00 \%$ & $73.00 \%$ \\
3 & Open & $60.90 \%$ & $69.90 \%$ & $80.00 \%$ \\
4 & Honest & $60.10 \%$ & $72.60 \%$ & $73.50 \%$ \\
5 & Objective & $47.50 \%$ & $67.00 \%$ & $74.90 \%$ \\
& Amount & 265.5 & 330.5 & 361.4 \\
& Average & $53.1 \%$ & $66.10 \%$ & $72.28 \%$ \\
\hline
\end{tabular}




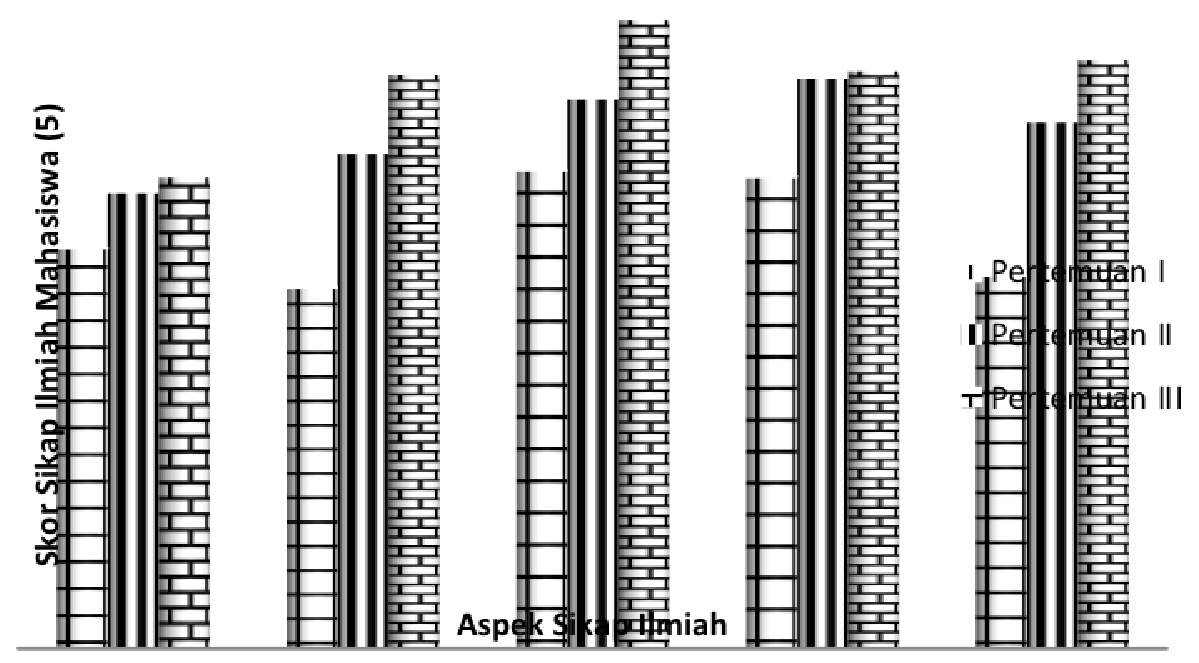

Figure1. Graph of the Percentage of Scientific Attitude.

According to the results of research obtained at SMA Negeri Suka Makmur Aceh Besar, the average value of the percentage of students' scientific attitudes during molluscs and anthropoids learning was increased. This shows that the learning process that has taken place can foster students' scientific attitudes. From each aspect, the average value of the highest and lowest scientific attitudes of students was obtained. The average value of the highest scientific attitude of students was on the open aspect of $70.27 \%$, while the average value of the lowest scientific attitude of students was on the curiosity indicator of $56.33 \%$.

The curiosity aspect was at an average percentage of $56.33 \%$. Based on the data obtained, the students did not seem all enthusiastic in finding answers to the questions given by the lecturer and did not read references related to the material taught via the internet and other reading sources. The students' curiosity was not so high in learning could be seen from the lack of effort made by the students in understanding a new concept. According to Yunita (2012), the level of scientific attitudes of students that can be seen from how they have very high curiosity to understand a new concept with their abilities without any difficulties, are critical of a problem that needs to be proven true, and evaluate their performance.

The critical aspect was obtained with an average percentage of $60.67 \%$. Lack of students' ability to think critically was such as expressing opinions or ideas during practical activities. Some students were still passive and did not participate in practicum activities due to a lack of knowledge and confidence in expressing their opinions, but some other students who were active in practical activities such as seeking additional information related to the material being taught and being able to express their opinions and complete data.

The average open aspect percentage was $70.27 \%$. The results showed that students were willing to exchange opinions during the vertebrate zoology practicum, and were able to reject the opinions of others if the opinions expressed were not true in a polite manner. The honest aspect got an average score of $68.73 \%$. Based on the molluscs and anthropoids practicum, it was known that students are in a group that has been determined by the teacher and did not provide leaked answers during the evaluation of the practicum took place.

The objective aspect obtained an average percentage value of $63.13 \%$. The results showed that the activities of students to carefully examine the reports that had been written 
during the molluscs and anthropoids took place well about $60 \%$, but there were also $40 \%$ of students who were less careful in preparing reports on practical activities.

During the process of practicum activities, teachers should train and cultivate students' scientific attitudes such as curiosity, critical, open, honest, and objective. Inquiry learning has several advantages from the aspect of the nature of the scientific inquiry. This learning approach can be used to develop additional understanding concepts for students. On the other hand, this approach provides benefits for students with weak abilities.

\section{Conclusions}

Based on the results of research on practicum-based inquiry learning on the concepts of molluscs and anthropoids to improve students' scientific attitudes, it can be concluded that the student learning outcomes increase with practicum-based inquiry learning on the concept of molluscs and anthropoids. In addition, students' science process skills on the concept of molluscs and anthropoids through practical-based inquiry learning were increased progressively.

\section{References}

Dimyati and Mudjiono. (2006). Study and Learning. Jakarta: Rineka Cipta.

Djamarah, S.B. (1996). Learning Psychology. Bandung: Rineka Cipta.

Elster, D. (2011). "Inquire for Students" - How to Promote Inquiry Based Learning?.International Conference. New Perspective in Science Education.University of Bremen, Institute of Biology Education (Germany).

Ibrahim, M. (2007). Inquiry Learning. http://www.kpicenter.org.

Joyce, W. B.\& Shower, B. (2000). Models of Teaching, Fourth Edition. Massachusetts: Allyn and Bacon Publishing Company

Ministry of Education and Culture (2013). Basic Competencies Curriculum 2013 SMA/MA. Jakarta: Ministry of National Education

Kurniati, T. (2001). Learning Process Skills Approach To Improve Students' Critical Thinking Skills. Thesis PPs UPI. Bandung: Unpublished.

Meltzer, DE (2002). The Relationship Between Mathematics Preparation and Conceptual Learning Gains in Physics: A Possible "Hidden Variable" in Diagnostic Pretest Scores. Journal of am J Phys. 70 (12). 1260.

Pascaldaddy. (2008). Application of Practicum Methods in Improving Students' Chemistry Learning Outcomes in the Subject of Acids and Bases in Junior High School. https://pascaldaddy512.com/penelitian-penerapan-metode-praktikum-dalammeningkatkan-hasil-belajar-kimia-siswa-dalam-pokok-bahasan-asam-dan-basa-di$\mathrm{smp} /$.

Pujianto, S. (2013). Exploring the World of Biology. Jakarta: Platinum

Purwanto, N. (2002). Educational Psychology. Bandung: PT Pemuda Rosdakarya

Sutrisno, J. (2008).The Influence of Inquiry Learning Method in Learning Science on Students' Learning Motivation.http://www.erlangga.co.id.

Sagala, S. (2008). The Concept and Meaning of Learning to Solve the Problems of Learning \& Teaching. Bandung: Alpha Beta

Slamet. (2003). Learning and the Factors That Affect It. Jakarta: Rineka Cipta 
Shah, M. (2003). Teaching and Learning Psychology. Jakarta: PT. King Grafindo Persada. Surtiana, (2002). Efforts to Improve Student Learning Outcomes on the Concept of Direct Current Electric Circuits Through Laboratory Activities. Thesis SPS UPI. Bandung: Unpublished.

Slavin, E.R. (1994). Educational Psychology Theory into Practices,Fourth Edition. Boston: Allyn and Bacon Publishers.

Siegel, S. (1992). Non-Parametric Statistics for Social Sciences. Jakarta: Gramedia.

Semiawan, C. (1992). Process Skills Approach. Jakarta: Gramedia

Stenberg. R. J. (2006).Cognitive Psychology, 4th Edition. Belmont CA, USA: Thomson Higher Education

Trianto. (2010). Designing an Innovative-Progressive Learning Model. Jakarta: Kencana Prenada Media Group

Tohirin. (2006).Psychology of Islamic Religious Learning. Jakarta: Raja GrafindoPersada.

Widoyoko. (2009). Learning Program Evaluation. Yogyakarta: Student Library

Wulan, A.R. (2008). Penilaian Kinerja dan Portofolio pada PembelajaranBiologi. Handout. FPMIPA-UPI.

Widodo, A., \& Ramdaningsih, V. (2006). Analisis Kegiatan Praktikum Biologi dengan Menggunakan Video. Metalogika. 9(2), 146-158. 